\title{
EVALUATION OF POSTFIRE RESTORATION IN SUBURBAN FOREST OF THESSALONIKI, NORTHERN GREECE
}

\author{
I. SPANOS ${ }^{1}$ \\ P. GANATSAS ${ }^{2, *}$ \\ M. TSAKALDIMI ${ }^{2}$
}

\author{
${ }^{1}$ NAGREF, Forest Research Institute, \\ 570 06, Vassilika, Thessaloniki, Greece \\ ${ }^{2}$ Aristotle University of Thessaloniki, \\ School of Forestry and Natural Environment, \\ Laboratory of Silviculture \\ P.O. Box 262, 54124, Thessaloniki, Greece
}

Received: 27/02/09

Accepted: 10/11/09 *to whom all correspondence should be addressed: e-mail: pgana@for.auth.gr

\begin{abstract}
Postfire plantation results and pattern of natural revegetation process were monitored for six years after wildfire in the artificial Pinus brutia forest of the suburban park of Thessaloniki, northern Greece. Some flood-preventing treatments and plantings took place on half of the burned area immediately after the fire, while the rest of the burned area was left to regenerate naturally. Based on the survival rate and growth of the planted species, the establishment of plantations was considered satisfactory six years after the fire. The pattern of postfire regeneration of Pinus brutia was similar in both planted and non-planted areas, although the saplings' density was significantly higher in the non-planted areas (4,145 saplings per hectare compared to 1,841 saplings per hectare in the planted burned areas). The former saplings' density can secure the species dominance in future stands, that means an auto-succession pattern ensues in this case, while the lower saplings' density of $P$. brutia in the planted areas, does not secure species dominance in future stands. This suggests that a mixed forest will be established in this case as a result of the plantings and pine natural regeneration. In both cases the sprouted shrubs Quercus coccifera and Phillyrea latifolia will accompany the stand structure appearing in the shrub story.
\end{abstract}

KEYWORDS: natural revegetation, Pinus brutia, postfire reforestation, wildfires.

\section{INTRODUCTION}

Wildfires are events that are an integral part of Mediterranean ecosystems (Di Castri and Mooney, 1973; Trabaud, 1994). Forests of Pinus brutia belonging to Mediterranean fire-damaged ecosystems are well-adapted to natural regeneration after fire (Neyiski, 1999; Ne'eman, 1993; Thanos and Doussi, 2000; Tavsanoglou and Gurkan, 2009). Thus, postfire natural regeneration of the species has been recorded in many parts of the Mediterranean basin (Thanos et al., 1989; Thanos and Markou, 1991; Spanos, 1992; Spanos et al., 2000a; Spanos et al., 2001; Boydak, 2004). However, postfire natural regeneration is limited under some circumstances (Eron, 1987) such as in the case of steep slopes or frequent fires (Tsitsoni, 1997; Raftoyannis and Spanos, 2005; Goudelis et al., 2007). Frequent fires can usually lead to smaller seed bank, bad soil conditions for seed germination and seedling establishment, as well as an increase in the risk of soil erosion, floods, etc. (Spanos et al., 2005; Goudelis et al., 2007). In these cases, as well as in the cases when other external causes exist (such as human demands, great erosion problems or requests for species change), an artificial input is necessary in order to improve or to accelerate forest establishment. Plantings are the common technique in these cases (Wang et al., 2007).

Factors influencing the postfire restoration process are ranked as the burned severity, way of restoration (planting, promoted restoration or natural restoration) and topographical factors (Li et al., 2006; Xie et al., 2008). Several studies have shown the great importance of human management 
after fire on burned ecosystems recovery process. Grazing is considered a strong negative factor (Spanos, 1992; Spanos et al., 2000a). Postfire silvicultural treatments play an important role on regeneration success (Martinez-Sanchez et al., 1999; De las Heras et al., 2004).

Postfire planting is considered a successful method for helping the recovery of the ecosystem in cases where natural revegetation is limited (Vallejo et al., 1999). Planting can accelerate the rate of canopy closure as well as the ecosystem resilience (Zagas et al., 2004), especially in sites where there are adverse site conditions, such as those existing in many postfire conditions and bad site qualities (Ganatsas et al., 2004; Wang et al., 2006). Tree planting was also found to have a large influence on age structure, spatial pattern and wood stock of dominant species in the postfire conditions (Li et al., 2006).

However, although there are many studies concerning tree plantings on poor, hot and dry sites (Bacilieri and Piussi, 1989; Pausas et al., 2004), only a few studies have been conducted in the Mediterranean basin, examining plantings effectiveness with broadleaved species under adverse postfire environments (Spanos et al., 2000b; Tsakaldimi, 2001; Ganatsas et al., 2003). Especially, studies comparing ecosystem recovery, under the natural regeneration process (passive restoration) and under the human interventions (active restoration techniques) such as planting or seeding, in the same postfire conditions, are rare globally (Moreira et al., 2009). These studies are very useful in order to select the appropriate method for restoration of burned areas.

Thus, the main objectives of the present study were: i) to identify the postfire colonization pattern of natural regeneration of Pinus brutia in different site qualities and different exposures, ii) to estimate the effect of plantings on postfire species composition, iii) to determine the temporal patterns of survival and growth of the planted species in different site qualities, and iv) to evaluate any differences in plant communities recovery between the planted and unplanted areas during the 6 years after the fire.

\section{MATERIAL AND METHODS}

\subsection{Study area}

The suburban Forest Park of Thessaloniki lies in north Greece $\left(40^{\circ} 39^{\prime} \mathrm{N}, 23^{\circ} 00^{\prime} \mathrm{E}\right)$, close to and uphill of the city of Thessaloniki, and covers an area of 2,979 ha (Figure 1). The dominant tree species is Pinus brutia, and in some locations Cupressus sempervirens, Cupressus arizonica, $P$. halepensis and $P$. pinea. The vegetation of the area belongs to the lowest part of the Mediterranean vegetation zone Quercetalia pubescentis, and specifically to the sub-zone Ostryo-Carpinion and the association Coccifero-Carpinetum (Dafis, 1973). The altitude of the area ranges from 100 to $450 \mathrm{~m}$. According to the climatic data taken from the meteorological station of Forest Research Institute of Thessaloniki, the climate of the area is a typical Mediterranean climate with a cold winter, high temperatures in the summer and an average annual precipitation of $416 \mathrm{~mm}$. The dry season lasts from May to the middle of September. According to the formula of Emberger (1971), the pluviothermic quotient $(\mathrm{Q})$ is 46.7 and the climate is characterized as cool and semiarid. Geologically, the area belongs to the magmatic series of Chortiatis and consists mainly of greenschists. The soils are shallow, infertile, of low productivity, and heavily degraded. They are slightly acid up to neutral, and are characterized by weak structure, low porosity, and a high percentage of stones and pebbles. The main benefits are recreation, the maintenance of landscape diversity and the protection of the city of Thessaloniki from floods, soil erosion and air pollutants. The forest presents great importance since it constitutes a unique 'greenbelt' for a fast developing city (Tsitsoni et al., 2004).

\subsection{The wildfire of 1997 and actions taken}

A large fire occurred in the forest on 6 July 1997. Over 1,500 ha of forest were burned, and half of the forest was completely destroyed. Immediately after the fire, eco-engineering and flood protection actions (logging of burned trunks, branch nettings, soil ripping, log lines, wooden barriers, etc) were carried out by the Local Forest Service in order to protect the city of Thessaloniki from flood and soil erosion. Additionally, during the period November 1997-February 1998, half of the burned area (800 ha) was planted with several forest species, while the rest area was left to regenerate naturally. 


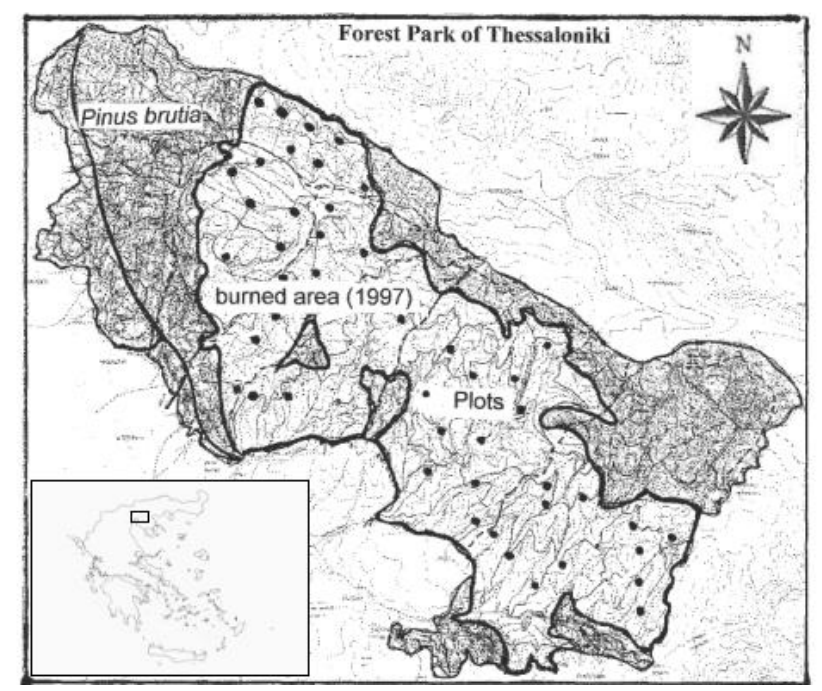

Figure 1. Map of the study area (suburban Forest Park of Thessaloniki) that is located in northern Greece. Light grey shows the burned area and the dark grey the un-burned forests. • symbols show the plot position

In the planted area, the soil was ripped up, in order to increase water infiltration and absorption of precipitation as well as to prepare the site for plantings. Two planting methods were used; planting in ditches along the contour lines with a ripper, and planting into holes; in both cases the planting spacing was $2 \mathrm{~m} \times 3 \mathrm{~m}$, thus the final plant density was approximately 1,650 trees per hectare. Twelve species were used to cover $85 \%$ of the total reforested area. The aim of species selection was to change the forest composition, so that the future forest would consist of conifers mixed with broadleaved species. The broadleaved species used were Quercus pubescens, Celtis australis, Quercus ilex, Fraxinus oxycarpa, Fraxinus ornus, Cercis siliquastrum and Robinia pseudoacacia and the conifers Pinus pinea, Cupressus sempervirens, Cupressus arizonica, Cedrus deodara and Cedrus atlantica. However, Quercus pubescens was by far the most widely used species covering a $40 \%$ of the planted area. Most of the species used were native and only few non-native ( $R$. pseudoacacia, C. arizonica, C. deodara and C. atlantica). The non-native species were selected by the Forest Service in order to improve the aesthetic value of the suburban forest, even though it is well documented that native species should be preferred in reforestation projects (Vallejo et al., 1999). Species spatial differentiation was done in patches of 0.30-5.0 ha, randomly selected by the Forest Service during the planting.

\subsection{Methods}

In 1998, immediately after planting, 50 permanent sample plots, each $500 \mathrm{~m}^{2}(20 \times 25 \mathrm{~m})$ in size, were established in the burned area; half in the planted areas, where the soil had been stirred up with a ripper, and half in the burned unplanted areas. The main factors taken into consideration for the selection of plots were site quality and exposure. Site quality refers to the combination of physical and biological factors characterizing a particular geographic location or site and may involve a descriptive classification (Skovsgaard and Vanclay, 2008). In forestry, site quality expresses an estimation of present and future forest productivity and provides a frame for land management; the terms good, medium (or fair) and poor are frequently used that simply imply a high productive potential as opposed to a medium or low potential (Clutter et al., 1983). Site quality in the area was classified as good, fair and poor, based on the results of previous studies in the area (Radoglou, 1987; Gatzogiannis et al., 1996).

Woody species natural regeneration was monitored in five sub-plots of $16 \mathrm{~m}^{2}(4 \times 4 \mathrm{~m})$ that were established on the four corners and in the center of each sample plot. Monitoring was carried out in April 1998, June 1998 (immediately after heavy rainfalls in May), October 1998, and during October of the five following years (1999-2003). In each sub-plot the following data were taken: number of individuals per species, species and total vegetation cover using a transect method estimation along the two borders lines of each subplot (Raftoyannis and Spanos, 2005), and stem height of all individuals. 
In order to estimate the performance of the planted species, in each of the 25 sample plots in the planted area, the number and the height of all planted trees were measured annually for the next six years. However, since the 25 plots were not enough to cover the twelve studied species, and the statistical error was high, additional plots were established in order to have at least one plot per species per site quality (at least 3 plots per planted species). Thus, 80 circular plots (radius $=5 \mathrm{~m}$ ) were established by a random selection, spread over all the burned planted area. Totally eight inventories were made over the six years following the wildfire (May 1998, Oct.1998, May 1999, Oct. 1999, Oct. 2000, Oct. 2001, Oct. 2002 and Oct. 2003).

The nomenclature of plant species follows Flora Europaea (Tutin et al., 1968-1980).

\subsection{Statistical analysis}

Statistical analysis was accomplished using the SPSS program. Differences for all variables between treatments were analyzed using analysis of variance and means were compared with Tukey's multiple comparison test. Seedlings density of Pinus brutia was compared between planted and non-planted areas and in different site qualities and exposures, for six years after the wildfire. Means of survival $(\%)$ and height $(\mathrm{cm})$ for the planted species were compared for six years (19982003) within all the different site qualities. Ground cover of the main shrub species was compared between planted and non-planted species. All tests for significance were conducted at $P=0.05$, unless otherwise indicated. The percentages were transformed to arsine square root values before analysis (Snedecor and Cochran, 1988; Norusis, 2002).

\section{RESULTS}

\subsection{Postfire natural regeneration pattern}

The natural regeneration establishment (progress) of $P$. brutia, during six years after the wildfire, in planted and non-planted areas is shown in Figures 2 and 3.

P. brutia seedlings firstly emerged four months after the fire (in November 1997); however, these seedlings suffered high mortality during the first postfire winter, due to early frosts, and finally their stem density in the spring (in the beginning of April 1998), was found very low, and ranged from 283 to 568 seedlings/ha (for planted and non-planted areas respectively). The main wave of $P$. brutia seedlings' emergence started from the first postfire spring (April-May 1998). The first postfire summer period caused a decrease in $P$. brutia seedlings' density, while after this period almost all seedlings managed to survive. However, in non-planted areas the seedlings' mortality was much lower $(2.6 \%)$ than that in planted areas $(21.3 \%)$. The maximum density of pine seedlings was observed one year after the fire (June 1998) for both treated areas. During the second postfire autumn (mainly in November '98) a small number of pine seedlings appeared (48 and 102 seedlings/ha for planted and non-planted areas respectively). Actually, $P$. brutia postfire regeneration was established during the first two years after the fire, and afterwards no seedling emergence was observed, following the same pattern in both planted and non-planted burned areas. In the planted areas, the stem density of pine seedlings was always significantly lower than that in the non-planted areas. Six years after the fire, the stem density of pine saplings was found 1,841 and 4,145 saplings/ha in the planted and non-planted areas respectively.

The rate of pine seedlings' appearance was affected by site quality (Figure 2) and site exposures (Figure 3). There were significant differences between the contrasted site qualities (good and poor) and the two treatments (planted and non-planted areas) during the whole monitoring period. Pine saplings' density was highest on north-facing sites, followed by those growing on east-, west- and south-facing sites on both planted and non-planted burned areas. Stem density on south-facing sites was found significantly reduced in October 1998, because of the seedlings mortality due to the summer drought.

Apart from the natural regeneration of $P$. brutia, almost all the shrub species existing before the fire appeared immediately after the fire by resproutings or from seeds. Table 1 shows the ground cover (\%) of the dominant shrub species found in planted and non-planted areas (May 2003). It is remarkable that the total ground cover of the naturally regenerated species was significantly higher in non-planted areas than in planted ones. Also, the ground cover percentage of the species Quercus coccifera, Cistus incanus, Phillyrea latifolia was significantly greater in non-planted areas. The most widespread species in both treated areas were the two resprouters Quercus coccifera and Phillyrea latifolia and the two seeders Cistus incanus and Anthyllis hermaniae. Other species found 
were the woody shrubs Asparagus acutifolius, Sarcopoterium spinosum, Crataegus monogyna and Jasminus fruticans, and much more sparsely the shrubs Arbutus unedo, Pistacia terebinthus, Paliurus spina-cristi and the tree species Carpinus orientalis, Celtis australis, Cercis siliquastrum, Fraxinus ornus, Juniperus oxycedrus, Quercus pubescens and Ulmus campestris.

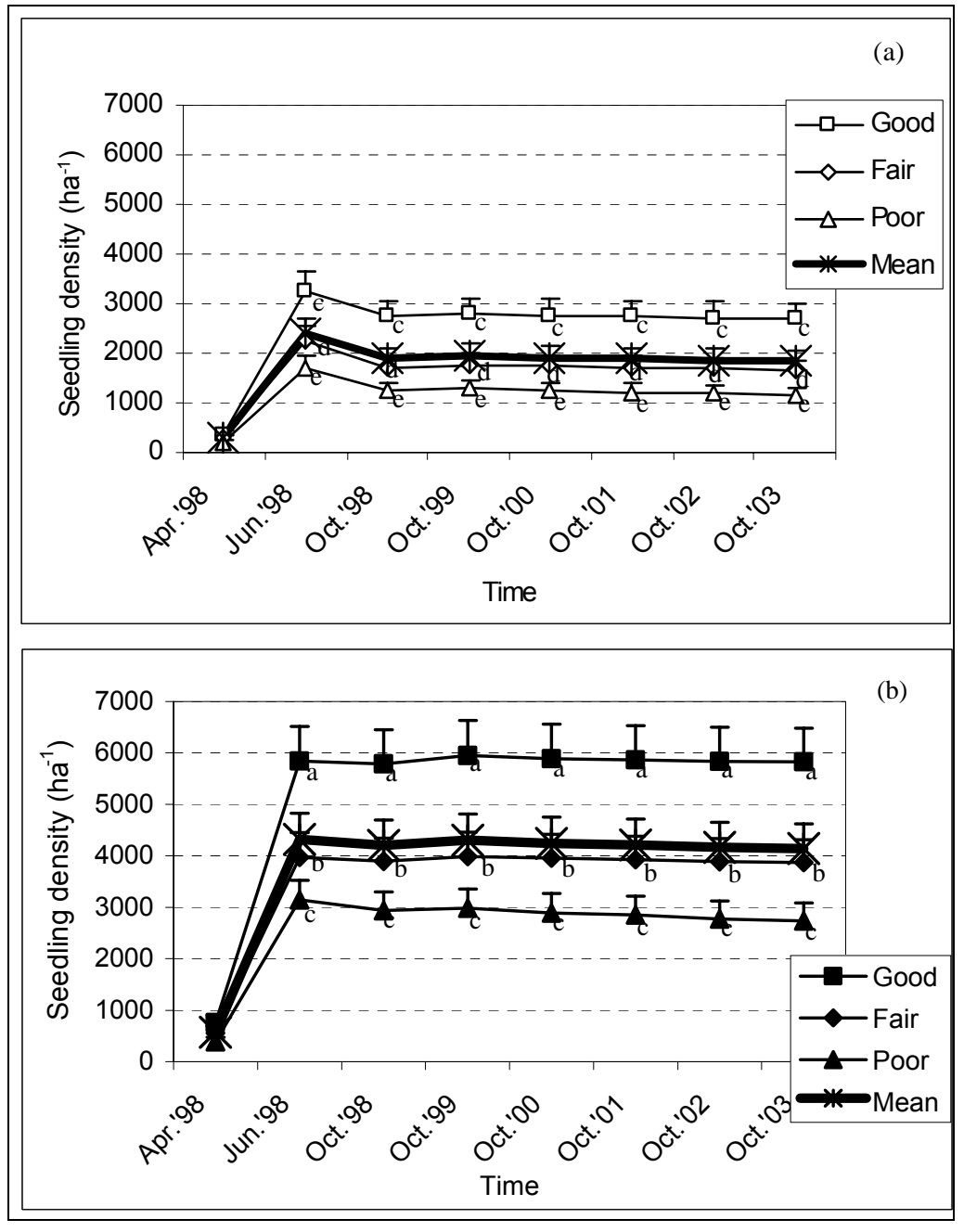

Figure 2. Postfire establishment of Pinus brutia in planted (a) and non-planted (b) burned areas and in different site qualities. The vertical bars represent the standard error. The different letters at a date indicate the statistical significant differences $(P<0.05)$ in seedling density, among the different categories

\subsection{Planting performance}

Planted species exhibited differences in field performance. Survival rates ranged greatly between the species reflecting their physiological features (Figure 4). Similar differences were observed in their growth. However, concerning the survival rate, among the twelve studied species, only one broadleaved species (Quercus ilex) exhibited low survival rates on all site qualities $(39 \%, 24 \%$ and $21 \%$ in good, fair and poor sites respectively) at the end of the crucial second postfire year (October 1999). The rest species exhibited satisfactory survival rate $65 \%$ in good, $64 \%$ in fair, and $62 \%$ in poor sites). Similar results were observed in the last inventory (Oct. 2003) six years after the fire; the survival rate of the eleven species was over $50 \%$ almost in all cases $(56 \%, 52 \%$ and $49 \%$ in good, fair and poor sites respectively). In contrast, Quercus ilex showed a very low survival rate on all sites (22\%, $15 \%$ and $10 \%$ respectively). 

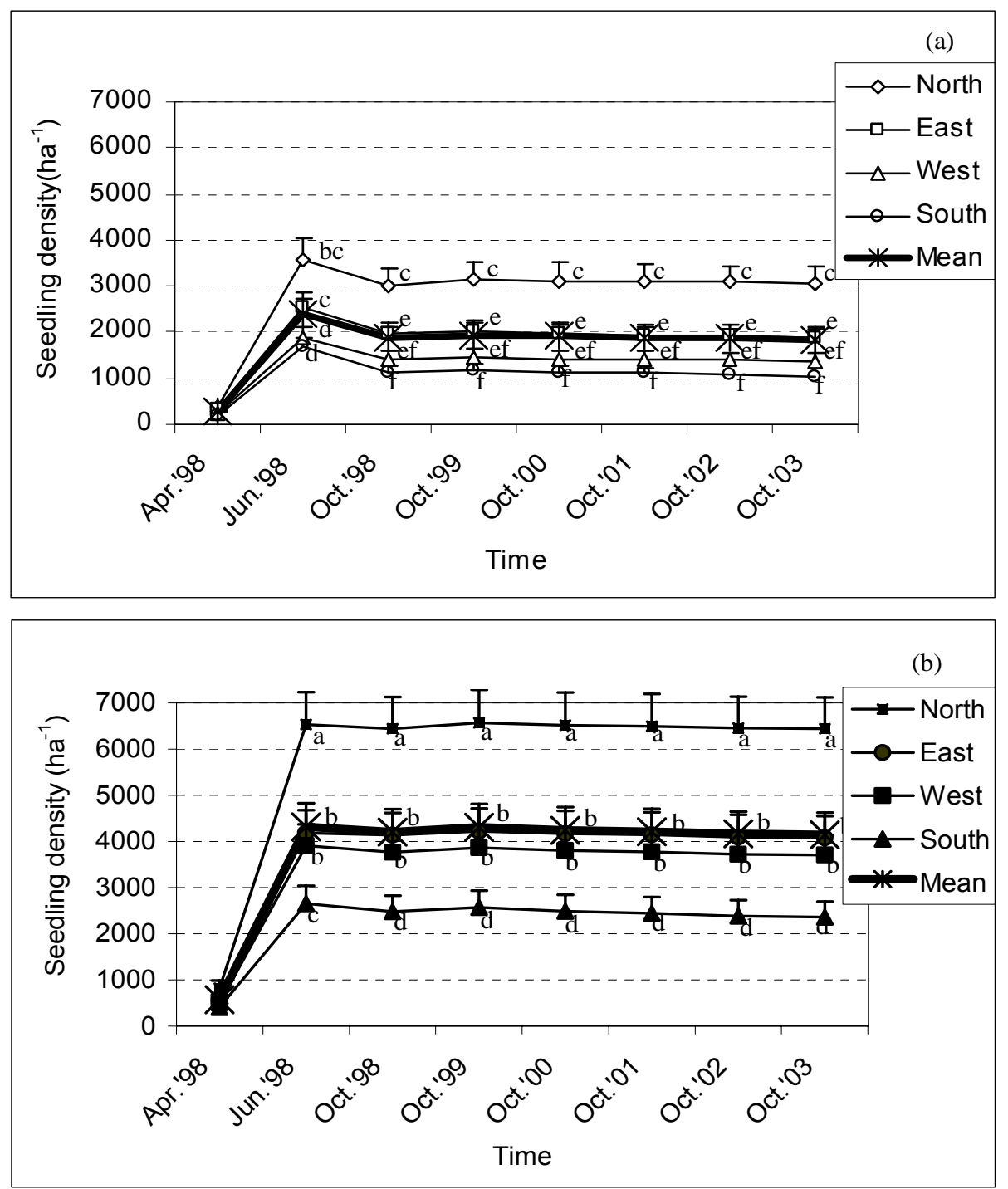

Figure 3. Postfire establishment of Pinus brutia in planted (a) and non-planted (b) burned areas and in different exposures. The vertical bars represent the standard error. The different letters at a date indicate the statistical significant differences $(P<0.05)$ in seedling density, among the different categories

Table 1. Mean ground cover (\%) ( \pm s.e.) of the main shrub species found in the planted and nonplanted burned areas (May 2003). Means of the same species followed by different superscript letter are significantly different (Tukey's test, $\mathrm{P}<0.05, \mathrm{n}=25$ )

\begin{tabular}{llc}
\hline Species & \multicolumn{3}{c}{ Ground cover $(\%)$} \\
& Planted areas & Non-planted areas \\
\hline Quercus coccifera & $22.1( \pm 4.3)^{\mathrm{b}}$ & $31.2( \pm 5.3)^{\mathrm{a}}$ \\
Cistus incanus & $17.9( \pm 3.9)^{\mathrm{b}}$ & $23.3( \pm 4.8)^{\mathrm{a}}$ \\
Phillyrea latifolia & $5.1( \pm 0.9)^{\mathrm{b}}$ & $6.9( \pm 1.2)^{\mathrm{a}}$ \\
Anthyllis hermaniae & $4.8( \pm 1.3)^{\mathrm{ns}}$ & $3.8(1.0)^{\mathrm{ns}}$ \\
Asparagus acutifolius & $2.1( \pm 0.9)^{\mathrm{ns}}$ & $1.6( \pm 0.6)^{\mathrm{ns}}$ \\
Sarcopoterium spinosum & $2.3( \pm 0.7)^{\mathrm{ns}}$ & $1.8( \pm 0.7)^{\mathrm{ns}}$ \\
Crataegus monogyna & $0.5( \pm 0.3)^{\mathrm{ns}}$ & $0.4( \pm 0.2)^{\mathrm{ns}}$ \\
Jasminus fruticans & $0.4( \pm 0.1)^{\mathrm{ns}}$ & $0.3( \pm 0.1)^{\mathrm{ns}}$ \\
\hline Total & $55.2( \pm 9.3)^{\mathrm{b}}$ & $69.3( \pm 10.7)^{\mathrm{a}}$ \\
\hline
\end{tabular}



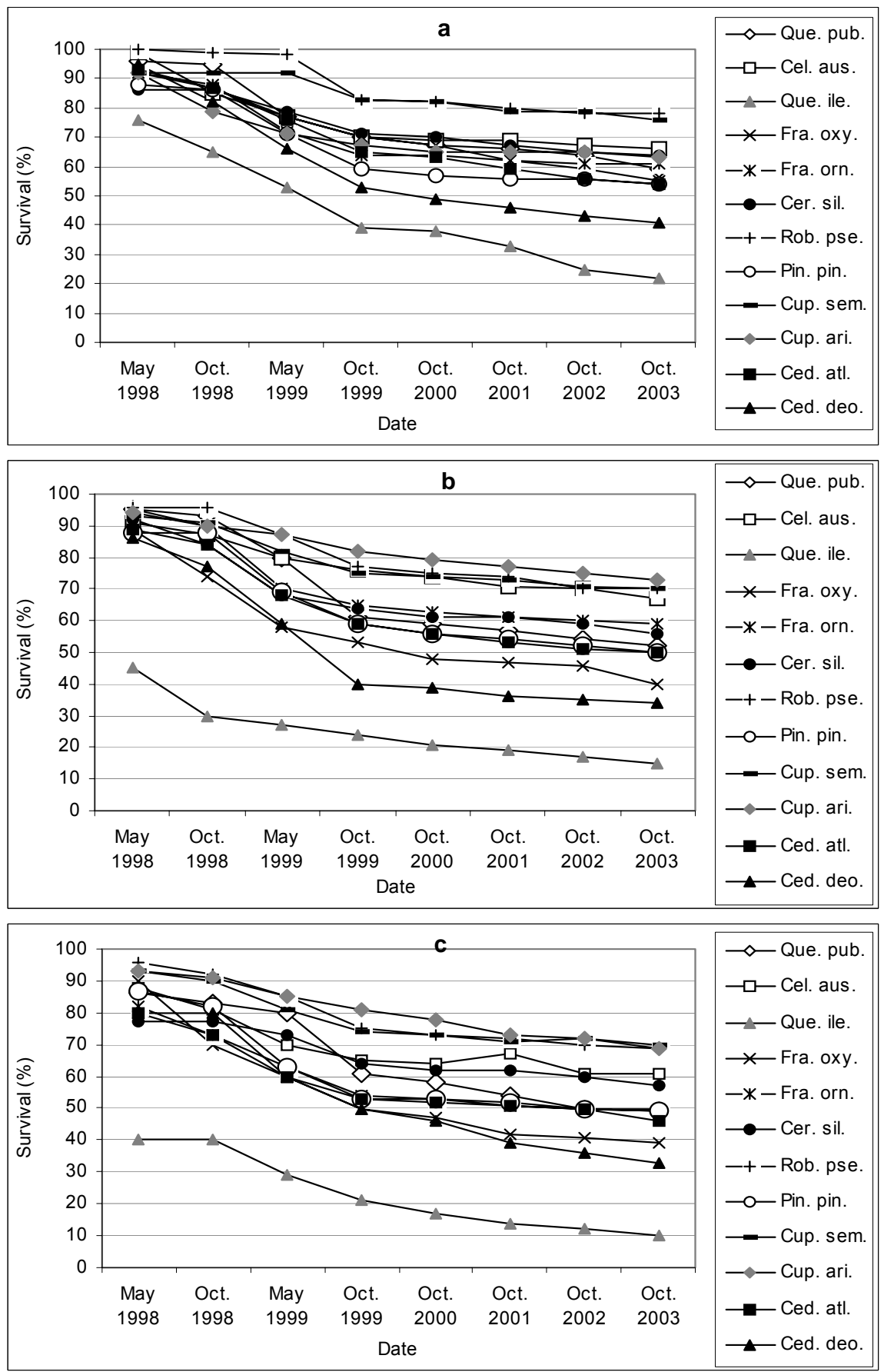

Figure 4. Postfire monitoring of the mean survival of the planted species in each site quality (a: good, b: fair, and c: poor)

Plant height growth greatly ranged between the planted species during the two crucial growing periods after the fire, as well as in the last inventory, six years after the fire (October 2003) (Table 2). The fastest growing species in height was Robinia pseudoacacia (mean height $225.0 \mathrm{~cm}$ ) and the slowest Quercus pubescens (mean height $45.5 \mathrm{~cm}$ ). The conifers Cupressus sempervirens and $C$. arizonica and the broadleaved species Celtis australis and Fraxinus ornus showed also good growth. It must be noted that the three main naturally regenerated species ( $P$. brutia, Quercus coccifera and Phillyrea latifolia) showed particularly good height growth (mean height $143.2 \mathrm{~cm}$, $145.5 \mathrm{~cm}$ and $149.3 \mathrm{~cm}$ respectively) in the planted areas, six year after the fire.

Table 2. Postfire monitoring of the mean height ( \pm s.e.) of the planted species. Among the species (of the same site quality and date), means followed by different superscript letter are significantly different (Tukey' test, $\mathrm{P}<0.05, \mathrm{n}=13$ ) 


\begin{tabular}{|c|c|c|c|c|c|c|c|}
\hline \multirow[b]{2}{*}{ Site quality } & \multirow[b]{2}{*}{ Tree species } & \multicolumn{6}{|c|}{ Height $(\mathrm{cm})$} \\
\hline & & $\begin{array}{l}\text { Planting } \\
\text { date } \\
\text { (Feb.1998) }\end{array}$ & $\begin{array}{l}\text { May } \\
1998\end{array}$ & $\begin{array}{l}\text { Oct. } \\
1998\end{array}$ & $\begin{array}{l}\text { May } \\
1999\end{array}$ & $\begin{array}{l}\text { Oct. } \\
1999\end{array}$ & $\begin{array}{l}\text { Oct. } \\
2003\end{array}$ \\
\hline Good & Quercus pubescens & $13.5^{\mathrm{a}}(0.3)$ & $14.5^{\mathrm{a}}(0.3)$ & $22.0^{\mathrm{a}}(0.4)$ & $23.2^{\mathrm{a}}(0.4)$ & $33.8^{\mathrm{a}}(0.6)$ & $53.8^{\mathrm{a}}(1.4)$ \\
\hline & Celtis australis & $25.1^{\mathrm{b}}(0.6)$ & $27.1^{\mathbf{b}}(0.6)$ & $47.2^{\mathrm{c}}(0.8)$ & $48.9^{d}(0.8)$ & $59.2^{d}(0.9)$ & $151.2^{\mathrm{d}}(4.6)$ \\
\hline$"$ & Quercus ilex & $26.2^{b}(0.8)$ & $28.1^{\mathrm{b}}(0.9)$ & $39.2^{\mathbf{b}}(1.3)$ & $40.2^{c}(1.3)$ & $45.9^{b}(1.5)$ & $93.2^{\mathrm{b}}(3.8)$ \\
\hline$"$ & Fraxinus oxycarpa & $32.4^{c}(1.2)$ & $34.2^{c}(1.2)$ & $48.6^{c}(1.6)$ & $50.1^{d}(1.7)$ & $68.4^{\mathrm{e}}(1.9)$ & $116.3^{c}(3.9)$ \\
\hline " & Fraxinus ornus & $29.1^{c}(1.1)$ & $31.8^{\mathbf{b}}(1.1)$ & $45.1^{\mathrm{c}}(1.6)$ & $48.7^{\mathrm{d}}(1.7)$ & $69.3^{\mathrm{e}}(2.0)$ & $155.2^{\mathrm{d}}(4.6)$ \\
\hline$"$ & Cercis siliquastrum & $18.0^{\mathrm{a}}(0.4)$ & $21.3^{\mathbf{b}}(0.4)$ & $35.6^{\mathbf{b}}(0.6)$ & $38.3^{c}(0.6)$ & $49.2^{b}(0.8)$ & $104.5^{c}(4.0)$ \\
\hline " & Robinia pseudoacac. & $33.1^{c}(1.0)$ & $35.7^{c}(1.1)$ & $56.3^{c}(2.0)$ & $59.5^{\mathrm{d}}(2.1)$ & $83.1^{f}(3.1)$ & $241.5^{f}(5.7)$ \\
\hline " & Pinus pinea & $10.1^{a}(0.1)$ & $11.2^{a}(0.1)$ & $25.3^{a}(0.4)$ & $27.6^{\mathrm{a}}(0 . .4)$ & $38.1^{b}(0.6)$ & $82.4^{\mathrm{b}}(2.1)$ \\
\hline " & Cupressus semper. & $15.1^{\mathrm{a}}(0.2)$ & $16.2^{a}(0.2)$ & $25.0^{a}(0.4)$ & $31.1^{\mathrm{b}}(0.4)$ & $57.2^{d}(0.7)$ & $163.1^{\mathrm{e}}(5.2)$ \\
\hline " & Cupressus arizonica & $13.1^{\mathrm{a}}(0.1)$ & $15.1^{\mathrm{a}}(0.1)$ & $32.3^{\mathbf{b}}(0.5)$ & $34.4^{\mathrm{b}}(0.5)$ & $62.6^{\mathrm{e}}(0.8)$ & $161.4^{\mathrm{e}}(5.0)$ \\
\hline " & Cedrus at & $10.3^{a}(0.2)$ & $11.2^{\mathrm{a}}(0.2)$ & $24.2^{\mathrm{a}}(0.4)$ & $25.0^{a}(0.4)$ & $48.9^{\mathrm{c}}(0.6)$ & $99.1^{b}(3.6)$ \\
\hline " & Cedrus deodara & $10.1^{a}(0.1)$ & $11.3^{a}(0.1)$ & $25.2^{a}(0.3)$ & $25.9^{\mathrm{a}}(0.3)$ & $49.4^{\mathrm{c}}(0.5)$ & $99.3^{b}(3.6)$ \\
\hline Fair & Quercus pubesce & $13.6^{\mathrm{a}}(0.2)$ & $13.9^{a}(0.2)$ & $21.1^{a}(0.4)$ & $22.4^{\mathrm{a}}(0.4)$ & $32.9^{a}(0.6)$ & $44.4^{\mathrm{a}}(1.8)$ \\
\hline " & Celtis australis & $24.9^{\mathrm{b}}(0.5)$ & $26.6^{\mathbf{b}}(0.5)$ & $46.7^{\mathrm{c}}(0.7)$ & $46.9^{c}(0.7)$ & $56.7^{c}(1.0)$ & $147.3^{\mathrm{e}}(4.5)$ \\
\hline 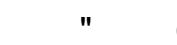 & Quercus ilex & $26.0^{\mathbf{b}}(0.8)$ & $27.2^{\mathbf{b}}(0.8)$ & $36.5^{\mathbf{b}}(1.2)$ & $38.2^{\mathbf{b}}(1.3)$ & $43.2^{b}(1.4)$ & $87.0^{c}(3.6)$ \\
\hline r & ycarpa & $32.2^{c}(0.9)$ & $33.4^{c}(0.9)$ & $46.4^{c}(1.3)$ & $48.6^{c}(1.3)$ & $67.2^{d}(1.7)$ & $109.6^{\mathrm{d}}(4.1)$ \\
\hline " & Fraxinus ornus & $29.0^{\mathbf{b}}(1.0)$ & $31.2^{c}(1.2)$ & $42.3^{c}(1.5)$ & $45.0^{c}(1.5)$ & $65.4^{\mathrm{d}}(1.8)$ & $147.1^{\mathrm{e}}(4.8)$ \\
\hline 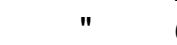 & Cercis siliquastrum & $18.2^{a}(0.5)$ & $20.4^{b}(0.5)$ & $33.0^{\mathbf{b}}(0.7)$ & $36.0^{\mathbf{b}}(0.7)$ & $42.5^{\mathrm{b}}(0.8)$ & $97.3^{\mathrm{d}}(3.8)$ \\
\hline & Robinia pseudoacac. & $33.0^{c}(1.2)$ & $34.0^{c}(1.2)$ & $53.5^{\mathrm{d}}(2.5)$ & $55.0^{d}(2.5)$ & $78.2^{\mathrm{e}}(3.0)$ & $227.3^{f}(5.1)$ \\
\hline " & Pinus pinea & $10.1^{\mathrm{a}}(0.1)$ & $10.5^{\mathrm{a}}(0.1)$ & $24.1^{\mathrm{a}}(0.3)$ & $24.6^{\mathrm{a}}(0.3)$ & $35.6^{\mathrm{a}}(0.5)$ & $75.5^{b}(1.9)$ \\
\hline & Cupressus semperv. & $14.9^{\mathrm{a}}(0.3)$ & $15.9^{a}(0.3)$ & $24.8^{a}(0.5)$ & $29.9^{a}(0.5)$ & $51.2^{\mathrm{C}}(0.8)$ & $155.4^{\mathrm{e}}(4.7)$ \\
\hline & Cupressu & $13.2^{\mathrm{a}}(0.2)$ & $14.2^{\mathrm{a}}(0.2)$ & $29.5^{\mathrm{a}}(0.4)$ & $31.2^{\mathbf{b}}(0.4)$ & $58.3^{c}(0.7)$ & $153.3^{\mathrm{e}}(4.7)$ \\
\hline " & Cedrus a & $10.2^{a}(0.1)$ & $10.6^{a}(0.1)$ & $22.1^{a}(0.3)$ & $22.9^{\mathrm{a}}(0.3)$ & $47.2^{b}(0.5)$ & $96.3^{\mathrm{d}}(3.8)$ \\
\hline " & Cedrus deodara & $10.2^{a}(0.1)$ & $10.4^{\mathrm{a}}(0.1)$ & $23.1^{a}(0.3)$ & $24.4^{\mathrm{a}}(0.3)$ & $46.2^{b}(0.5)$ & $97.1^{d}(3.7)$ \\
\hline Poor & Quercu & $13.4^{\mathrm{a}}(0.2)$ & $13.6^{a}(0.2)$ & $17.1^{\mathrm{a}}(0.3)$ & $17.7^{\mathrm{a}}(0.4)$ & $27.3^{\mathrm{a}}(0.7)$ & $38.0^{\mathrm{a}}(1.2)$ \\
\hline & Celtis & $25.3^{\mathbf{b}}(0.4)$ & $25.5^{\mathbf{b}}(0.4)$ & $39.5^{\mathrm{c}}(0.7)$ & $40.4^{d}(0.7)$ & $51.5^{\mathrm{d}}(1.0)$ & $142.8^{\mathrm{e}}(4.4)$ \\
\hline ( & Quercus ilex & $26.2^{\mathbf{b}}(0.9)$ & $27.0^{\mathbf{b}}(1.0)$ & $34.8^{\mathrm{c}}(1.3)$ & $35.1^{c}(1.3)$ & $39.6^{\mathbf{b}}(1.4)$ & $81.1^{\mathrm{c}}(3.4)$ \\
\hline & Fraxinus oxycarpa & $32.0^{c}(0.8)$ & $32.9^{c}(0.8)$ & $42.9^{d}(1.5)$ & $43.8^{d}(1.6)$ & $61.1^{d}(1.7)$ & $99.4^{\mathrm{d}}(4.0)$ \\
\hline & Fraxinus ornus & $29.2^{b}(0.8)$ & $30.5^{c}(0.8)$ & $41.2^{d}(1.6)$ & $42.1^{d}(1.7)$ & $58.2^{d}(1.9)$ & $142.0^{\mathrm{e}}(4.7)$ \\
\hline 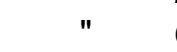 & Cercis siliquastrum & $18.1^{\mathrm{a}}(0.5)$ & $19.3^{\mathbf{b}}(0.5)$ & $30.2^{c}(0.6)$ & $32.4^{\mathrm{c}}(0.6)$ & $41.1^{c}(0.8)$ & $93.1^{\mathrm{d}}(3.9)$ \\
\hline & Robinia pseudoacac. & $33.2^{c}(1.2)$ & $33.6^{c}(1.2)$ & $47.9^{d}(2.3)$ & $51.1^{\mathrm{e}}(2.3)$ & $73.6^{\mathrm{e}}(2.6)$ & $206.4^{f}(5.2)$ \\
\hline & Pinus pinea & $10.2^{a}(0.1)$ & $10.3^{a}(0.1)$ & $20.5^{a}(0.4)$ & $21.2^{a}(0.4)$ & $30.4^{\mathrm{b}}{ }_{0}$ & $68.8^{\mathrm{b}}(1.8)$ \\
\hline " & Cupressus semper & $15.0^{\mathrm{a}}(0.3)$ & $15.5^{\mathrm{a}}(0.3)$ & $24.3^{\mathbf{b}}(0.6)$ & $28.7^{\mathbf{b}}(0.7)$ & $47.6^{c}(0.9)$ & $150.5^{\mathrm{e}}(4.9)$ \\
\hline & Cupressus arizonica & $13.1^{\mathrm{a}}(0.3)$ & $13.5^{\mathrm{a}}(0.3)$ & $28.6^{\mathbf{b}}(0.5)$ & $29.1^{b}(0.5)$ & $54.5^{\mathrm{d}}(0.8)$ & $149.2^{\mathrm{e}}(4.9)$ \\
\hline " & Cedrus atlantica & $10.2^{a}(0.1)$ & $10.2^{a}(0.1)$ & $19.6^{a}(0.3)$ & $20.8^{\mathrm{a}}(0.3)$ & $42.6^{c}(0.6)$ & $93.2^{d}(3.7)$ \\
\hline 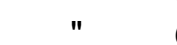 & Cedrus deodara & $100^{a}(0.1)$ & $103^{\mathrm{a}}(0,1)$ & $201^{a}(0.3)$ & $221^{\mathrm{a}}(0.3)$ & $429^{c}(0.5)$ & $92.2^{d}(3.8)$ \\
\hline
\end{tabular}

\section{DISCUSSION}

Postfire regeneration of $P$. brutia in the study area took place with a time delay, as has been observed in many similar sites (Thanos and Doussi, 2000). The main wave of $P$. brutia seedlings' emergence started from the first postfire spring, while the first postfire summer is by far the most crucial period for pine seedlings' survival. $P$. brutia postfire regeneration was established during the first two years after the fire and afterwards no seedling emergence was observed in both planted and non-planted burned areas. However, the natural regeneration of the study area was successful such as in Samos (Thanos et al., 1989; Thanos and Markou, 1991) and Thasos island (Spanos et al., 2000a, 2001). This means that postfire recovery of $P$. brutia forest is ensured in this area. Thus, natural regeneration is the best choice for restoration of the burned ecosystems in the area. Similar results were reported for Thasos Island (Spanos, 1992; Spanos et al., 2000a) where over $80 \%$ of the burned area was regenerated by $P$. brutia, although the burned areas were subjected to overgrazing by goats.

Site quality and slope orientation affected the revegetation process which was more successful on good sites and on the north slopes. Slope aspect has significant effects on the composition, structure and density of the plant communities in the postfire conditions (Tsitsoni, 1997), and should 
be a dominant parameter in the planning of post-fire management activities. The more abundant natural regeneration on north-facing sites, can be attributed to the more available soil moisture during the summer as the limiting factor for plant survival and growth in the area is considered the low soil water availability during the dry summer period (Radoglou, 1987; Ganatsas and Tsakaldimi, 2003).

However, in the cases when artificial input is necessary such as in the suburban forest of Thessaloniki, where there was a great demand for rapid forest re-establishment by the local residents (concerned about soil erosion, flooding, oxygen production generally, all the reasons that a greenbelt can be of benefit to a city) as well as for species change (from pine monoculture to mixed forest), planting of the appropriate species is the best choice. The primary consideration for planting in the area was the transformation from pure monoculture forest to mixed stands that usually are more stable and resilient to wildfires. A second consideration was the selection of suitable species that should be used under similar conditions.

The pattern of postfire regeneration of Pinus brutia was similar in both planted and non-planted areas. However, the pine density was significantly higher in the non-planted areas $(4,145$ saplings/ha six years after the fire) than that in planted ones, which is mainly attributed to the human interventions that had obstructed seed germination (Raftoyannis and Spanos, 2005) or the reduced available space. The quite high final stem density in the non-planted areas can secure the dominance of the species in postfire communities (Boydak, 2004), which means that a pure $P$. brutia forest will be created, with a shrubstory of $Q$. coccifera, $P$. latifolia and $C$. incanus. On the other hand, in the planted areas the final stem density of $P$. brutia was lower (1,841 saplings/ha) and does not secure species dominance (Boydak, 2004). This means that in this case a mixed forest will be established as a result of planting and the natural auto-succession process. This forest will be dominated by a conifer, the naturally regenerated $P$. brutia and by one of the main planted broaleaved species, those planted in the greater percentage (Quercus pubescens, Celtis australis, Fraxinus ornus). The stand composition seems to be in a ratio of $70 \%-60 \%$ participation of $P$. brutia and $30 \%-40 \%$ of the broadleaved species, if the mortality remains low during the following years. However, the main broadleaved species should be $Q$. pubescens which even though it exhibited low growth rate it was planted in the greater part of the burnt area $(180,000$ trees of the 500,000 planted were of this species).

In the composition of the plant community some shrub species will participate in both cases; these are mainly the shrubby species Quercus cocifera and Phillyrea latifolia, as well as the phryganic species Cistus incanus that were the most abundant shrub species before the fire.

\section{CONCLUSIONS}

Based on the findings of the study it seems that two different types of ecosystem will be created after the fire in the area. The first will appear in the non-planted area, where $P$. brutia postfire natural regeneration is quite good and it secures species dominance in the future stands. However, these stands will be pure pine stands with a shrubstory of the evergreen woody species mainly $Q$. coccifera and $P$. latifolia and $C$. incanus. The second type will be created in the planted burned area, where a mixed forest is anticipated. This forest will be composite by a pine ( $P$. brutia) and a broadleaved species, in most cases Quercus pubescens and in a few cases Celtis australis, Fraxinus ornus. The mixture will be per single tree or in small patches, while the differentiation of the co-dominant broadleaved species will be in patches of different size as a result of the plantation planning. Thus, in this case we exploit the self re-newing ability of the ecosystem (natural regeneration process of the pre-fire dominant species $P$. brutia) and simultaneously we lead to the formation of a mixed ecosystem by the artificial intervention (planting) which is more stable and resilient to wildfires. These results can have important implications for forest managers to design sound restoration projects for forest areas affected by large disturbances by fire.

\section{ACKNOWLEDGEMENTS}

This study is a part of a national ongoing programme financed by the Greek Ministry of Agriculture (General Secretary of Forests and Natural Environment). Many thanks to the staff of the Forest Research Institute of Thessaloniki; E. Xanthopoulou, T. Tsolakoglou and A. Tsolakis, as well as the foresters of the 
Reforestation Directorate of Thessaloniki; K. Tsiftelidis, I. Pinakidis, V. Athanasiadis and I. Stergiopoulos, for their assistance with field work. Additionally, many thanks to Bruce Nicoll, Forestry Commission Research Agency, Scotland, for his help with the written English in this paper.

\section{REFERENCES}

Bacilieri R., Piussi P. (1989), Reafforestation of Monte Argentaio (Tuscany). Italia Forestale e Montana, 44, 465-488.

Boydak M. (2004), Silvicultural characteristics and natural regeneration of Pinus brutia Ten. A review. Plant Ecol., 171, 153-163.

Clutter J.L., Fortson J.C., Pienaar L.V., Brister G.H., Bailey R.L. (1983), Timber Management: A Quantitative Approach. Krieger Publishing Company, Malabar, Florida.

Dafis S. (1973), Classification of vegetation in Greece (in Greek). Eds. Aristotle University of Thessaloniki, Vol IE., Thessaloniki.

De las Heras J., Gonzalez-Ochoa A., Lopez-Serrano F., Simarro M.E. (2004), Effects of silviculture treatments on vegetation after fire in Pinus halepensis Mill. woodlands (SE Spain). Ann. For. Sci., 61, 661-667.

Di Castri F., Mooney A.H. (1973), Mediterranean Type Ecosystems. Origin and Structure, Ecological Studies 7, Springer-Verlag, Berlin, New York.

Emberger L. (1971), Considerations complementaires au sujet des recherches bioclimatologiques et phytogeographiques, in: Emberger L.(Ed.), Travaux de botanique et d' ecologie, Masson et Cie, Paris, pp.291-301.

Eron Z. (1987), Ecological factors restricting the regeneration of Pinus brutia in Turkey. J. Medit. Ecol., 13, 57-67.

Ganatsas P.P., Tsakaldimi M.N. (2003), Root system modification of Pinus brutia Ten. species under adverse ecological conditions, in: Proceedings of the $8^{\text {th }}$ International Conference on Environmental Science and Technology, 8-10 September, Lemnos Greece, pp. 216-223.

Ganatsas P., Tsakaldimi M., Tsitsoni T. (2003), The use of oaks in reforestation in Greece, in: Proceedings of the $11^{\text {th }}$ Hellenic Forestry Conference, 1-3 October 2003, Olympia, Greece, pp.126132 (in Greek with English summary).

Ganatsas P., Tsitsoni T., Zagas T., Tsakaldimi M. (2004), Plantation contribution to restoration of degraded ecosystems in the alliance of Ostryo-Carpinion, in: Proceedings of the International Conference 'Protection and Restoration of the Environment VII', 28 June-1 July 2004, Myconos, Greece.

Gatzogiannis S., Kiriakidis P., Gigis, C. (1996), Administration Plan for the Forest Park of Thessaloniki (in Greek). NAGREF. Forest Research Institute. Thessaloniki. pp. 67.

Goudelis G., Ganatsas P., Spanos I., Karpi A. (2007), Effect of repeated fire on plant community recovery in Penteli, central Greece, in: Stokes, A., Spanos I., Norris J., Cammeraat E. (Eds.), Eco- and Ground Bio-engineering: The Use of Vegetation to Improve Slope Stability, Springer, pp.337-343.

Li X., Xie F., Wang X., Kong F. (2006), Human intervened post-fire forest restoration in the Northern Great Hing'an Mountains: a review. Landscape Ecol. Eng., 2, 129-137.

Martinez-Sanchez J.J., Ferrandis P., De las Heras J., Herranz J.M. (1999), Effect of burnt wood removal on the natural regeneration of Pinus halepensis after fire in a pine forest in Tus valley (SE Spain). For. Ecol. Manage., 123, 1-10.

Moreira F., Catry F., Lopes T., Bugalho M.N., Rego F. (2009), Comparing survival and size of resprouts and planted trees for post-fire forest restoration in central Portugal. Ecol. Eng., doi:10.1016/j.ecoleng.2008.12.017.

Ne'eman G. (1993), Regeneration of natural pine forest-review of the work done after the 1989 fire in Mount Carmel, Israel, Int. J. Wildland Fire, 7, 295-306.

Neyiski T. (1993), Ecological adaptive traits of Pinus brutia Ten. to fires, in: Papers of International Symposium on Pinus brutia Ten., Ministry of Forestry (Turkey), Marmaris, 18-23 October, 1993, pp.79-84.

Norusis M.J. (2002), SPSS 11.0 Guide to Data Analysis. Prentice Hall.

Pausas J.G., Blade C., Valdecantos A., Seva J.P., Fuentes D., Alloza J.A., Vilagrosa A., Bautista S., Cortina J., Vallejo R. (2004), Pines and oaks in the restoration of Mediterranean landscapes of Spain: new perspectives for an old practice-a review. Plant Ecol., 171, 209-220.

Radoglou K. (1987), Effect of the station on reforestation success and ecophysiological condition of trees in Kedrinos Hill of Thessaloniki. PhD Thesis. Aristotle University of Thessaloniki, dpt. of Forestry and Natural Environment. Thessaloniki, pp.173. (in Greek with English summary). 
Raftoyannis Y., Spanos I. (2005), Evaluation of log and branch barriers as post-fire rehabilitation treatments in a Mediterranean forest in Greece. Int. J. Wildland Fire, 14,183-188.

Skovsgaard J.P., Vanclay J.K. (2008), Forest site productivity: a review of the evolution of dendrometric concepts for even-aged stands. Forestry, 81, 13-31.

Snedecor G.W., Cochran W.G. (1988), Statistical Methods. The lowa State University Press.

Spanos I. (1992), Structure and regeneration of Pinus brutia in Thassos island. PhD Thesis. Aristotle University of Thesssaloniki, Vol.^Г/1990, pp.180. Thessaloniki. (in Greek with English summary).

Spanos I., Daskalakou E., Thanos K., (2000a), Postfire, natural regeneration of Pinus brutia in Thassos Island, Greece. Acta Oecol., 21, 13-20.

Spanos I., Chatiphilipidis G., Zagas T., Chatzistathis A., Pinakidis I., Athanasiadis V., Stergiopoulos I. (2000b), Post fire establishment of plantings in the suburban forest park of Thessaloniki; first results two years after the great fire. NAGREF, Athens, Dasiki Erevna 13, 11-25 (in Greek with English summary).

Spanos I., Radoglou K., Raftoyannis Y. (2001), Site quality effects on post-fire regeneration of Pinus brutia forest on a Greek island. App. Veg. Sci., 4, 229-236.

Spanos I., Raftoyannis I., Goudelis G., Xanthopoulou E., Samara T., Tsiontis A. (2005), Effects of postfire logging on soil and vegetation recovery in a Pinus halepensis Mill forest of Greece. Plant Soil, 278, 171-179.

Tavsanoglou C., Gurkan B. (2009), Postfire regeneration of a Pinus brutia (Pinaceae) forest in Marmaris National Park, Turkey. Inter. J. Bot., 5, 107-111.

Thanos A.C., Markou S., Christodulakis D., Yannitsaros A. (1989), Early post regeneration in Pinus brutia forest ecosystems of Samos Island (Greece). Acta Oecol., 10, 79-94.

Thanos A.C., Markou S. (1991), Post-fire regeneration in Pinus brutia forest ecosystems of Samos Island (Greece): 6 years after. Acta Oecol., 10, 633-642.

Thanos K., Doussi M. (2000), Post-fire regeneration of Pinus brutia forests, in: Ne'eman G., Trabaud L. (Eds.). Ecology, Biogeography and Management of Pinus halepensis and P. brutia Forest Ecosystems in the Mediterranean Basin, Backhuys Publishers, pp. 291-301.

Trabaud L. (1994), Postfire plant community dynamics in the Mediterranean basin, in: Moreno, J.M., Oechel, C. (Eds), The Role of Fire in Mediterranean-type ecosystems. Springer-Verlag, Berlin, pp. 1-15.

Tsakaldimi M. (2001), Research on the production and quality assessment of the container-planting stock used in the afforestations. Ph.D Thesis, Aristotle University of Thessaloniki, Dep. of Forestry and Natural Environment, Thessaloniki, pp.198.

Tsitsoni T. (1997), Conditions determining natural regeneration after wildfires in the Pinus halepnsis (Miller, 1768) forests of Kassandra Peninsula (North Greece). Forest Ecol. Manage., 92, 199-298.

Tsitsoni T., Ganatsas P., Zagas T., Tsakaldimi M. (2004), Dynamics of postfire regeneration of Pinus brutia Ten. in an artificial forest ecosystem of northern Greece. Plant Ecol., 171, 165-174.

Tutin T.G., Heywood V.H., Burges N.A., Valentine D.H., Walters S.M., Webb D.A., (1968-80), Flora Europaea, vols. 1-5, Cambridge University Press, Cambridge.

Vallejo R., Bautista S., Cortina J. (1999), Restoration for soil protection after disturbances, in: Trabaud, L. (Ed.), Life and Environment in the Mediterranean. Advances in Ecological Sciences 3. WIT Press, pp.301-343.

Wang X., He H.S., Li X. (2006), Assessing the cumulative effects of postfire management on the forest landscape dynamics in Northeastern China. Can. J. For. Res., 36, 1992-2002.

Wang X., He H.S., Li X. (2007), The long-term effects of fire suppression and reforestation on a forest landscape in Northeastern China after a catastrophic wildfire. Landscape and Urban Planning, 79, 84-95.

Xie F.J., Li X.Z., Wang X.G., Xiao D.N. (2008), Post-fire forest restoration indicated by canopy density in the Northern Great Hing' An Mountains, in: Hong S.K., Nakagoshi N., Fu B.J. and Morimoto Y., (Eds.). Landscape Ecological Applications in Man-Influenced Areas: Linking Man and Nature Systems, Springer Science + Business Media, pp. 359-374.

Zagas T., Ganatsas P., Tsitsoni T., Tsakaldimi M. (2004), Post-fire regeneration of Pinus hallepensis Mill. Stands in the Sithonia peninsula, northern Greece. Plant Ecol., 171, 91-99. 